\title{
REPETITIVE USE OF AHP-HIERARCHY
}

\author{
Matti Verkasalo \\ Nokia Telecommunications \\ Finland
}

Keywords Management, Decision Support Systems, Practice, Systems, Manufacturing

;

\begin{abstract}
It would be very beneficial to be able to use an AHP-hierarchy several times in decision problems, which are similar to each other. However, there are some methodological, mathematical and practical limits for copying a hierarchy from one case to another. This empirical study is focused to define the disciplines for repetitive use and to give some proposals for a practical implementation. The study concludes that the uppermost level of AHP-hierarchy with the judgements made can be used several times, if the decision problems are similar enough and thus belong to a specific group of problems. The argument given in the paper is that "a group of decision problems" is defined by four methodological limitations and three AHP-theory based limitations.
\end{abstract}

\section{Introduction}

There are a few decision support software (DSS) packages that have gathered a certain level of success during the late 80 's and early 90 's. It is a realistic assumption, that only the most enthusiastic ones keep using DSS continuously year after year. On many sectors of life there are many important decisions made where a structured decision process very probably led to a better solution than an unstructured and badly managed "this is the only possibility"kind of decision. We, the researcher and developers of decision methods and DSS-tools, cannot say that the users are stupid or lazy, because they don't use our methods and tools. The only way to widen the utilization of DSS is to find and invent new means to lower the psychological and practical barriers that keep the majority of potential users "hands off" away from DSS. This study was made in intention to lower the utilization barrier by rationalizing the repetitive decision processes. Verkasalo (1993) gave an outline of a new kind of enhanced DSS, that is needed in the repetitive use.

This study is based on five years experience of using a DSS-tool in technical and economical business decisions. The DSS used is Expert Choice, Forman (1993), that is based on the AHP - decision theory, Saaty (1980). However, there are no reasons to suspect that Expert Choice or AHP were somehow less advanced in this respect than some other tools or theories. In this study there are no comparisons made between several tools or theories.

The practical cases analysed in this study are from the electronics industry. On behalf of the subject, repetitive use of AHP-hierarchy, the cases could have been from any other sector as well. More important is that the cases are from a field, that the researcher manages deeply enough. 


\section{Problem definition}

\subsection{The field of research}

This study can be located in the bundle of decision making research and development according to the fig.1.
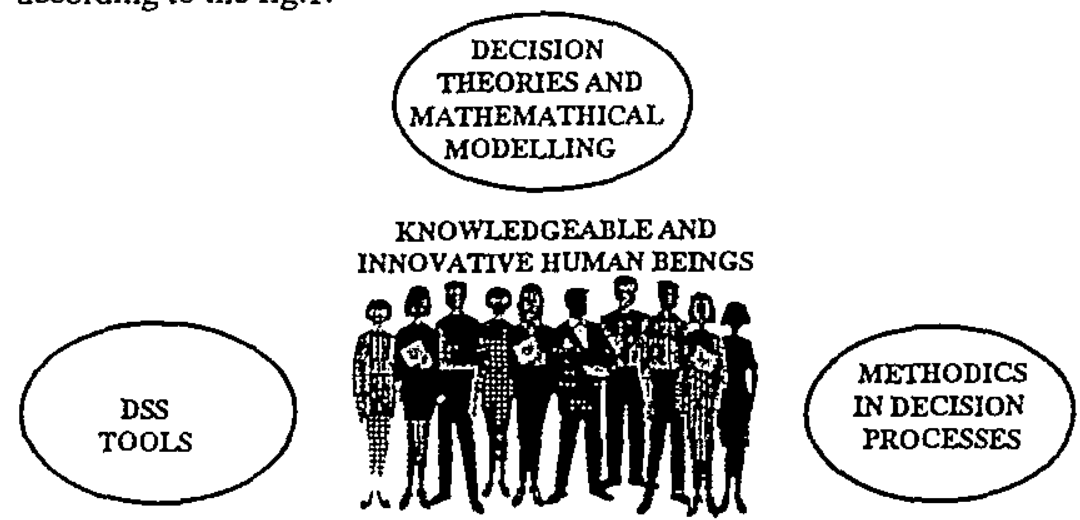

Fig.1 The three elements in decision making research and development

\section{DECISION THEORIES AND MATHEMATICAL MODELLING}

In this study there is no intention to further develop or modify any basic decision making theory, but the starting point is an established and well-formulated mathematical decision theory, AHP. AHP is based on pairwise judgement of elements to get a judgement matrix from which a eigenvector solution gives the priorities to the judged elements, Saaty (1980).

\section{DSS TOOLS}

In this study there will be some proposals made how the DSS-tools could be developed to help better repetitive decision making within a certain group of decision problems.

\section{METHODICS IN DECISION PROCESSES}

The subject of this study is decision making methodology on a specific field of expertise. Implementation of methodology is known to increase the successfulness of system design processes in concurrent engineering, Verkasalo (1989). Decision making is an essential part of system design.

The expertise field used in the study is production technology in electronics business. However, the study and the conclusions have been made in a form that they are usable also on other specific expertise fields. This study does not include any proving of this general usability of the formulated methodology.

\subsection{Problem definition}

The case company, Nokia Telecommunications, has based its success on very carefully made decisions in choosing some key technologies to be used either in the company's products or on the production lines. During the past 5 years there have been annually 3-4 important production technology decisions. "Important" decision is a one that has 
significant effect on the competitiveness of product or that leads to significant economical impacts. In some problems a DSS-tool, Expert Choice, Forman (1993), was used to help the team to find the best choice. In the AHP-hierarchy the upper part reflects mainly the longer term technology and business strategy of the company, and does not change significantly during one year. The lower part, the detailed criteria and alternatives are very problem specific, figure 2 .

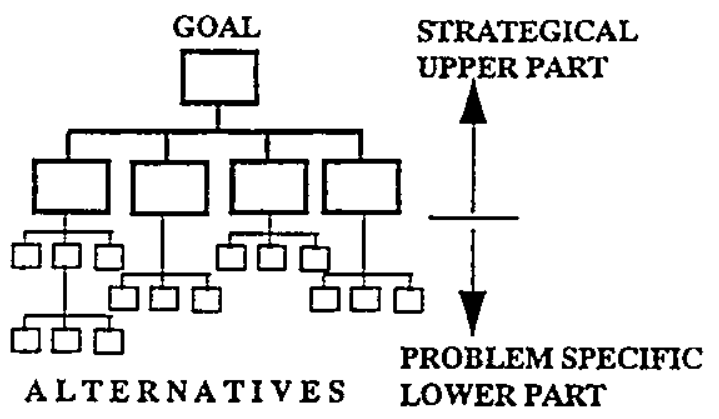

Fig.2 The uppermost level of AHP-hierarchy reflects the long term objectives

If we assume that AHP was used in all of these decision probiems, a very probable situation would have been that the same uppermost level of the AHP-hierarchy could have been used in the most of these cases. The repetitive production technology decisions form a group of problems like in the figure 3 and the uppermost level might be the same from i problem to problem.

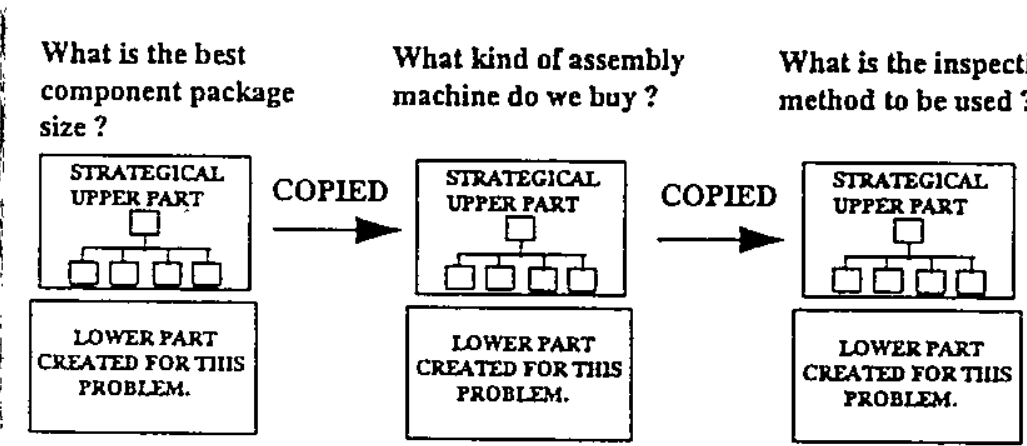

Fig. 3. Within a group of problems the uppermost level could be copied

\section{The problem definition of this study is:}

Can we copy the uppermost level of a AHP-hierarchy (the structure and the priorities) from one problem to another, if the cases belong to the same group of problems?

What are the disciplines for the copying? 


\section{Practical motivations/applications}

The motivation of this study is threefold:

- repetitive use of AHP-hierarchy transfers knowledge

The upper part of the hierarchy, in this case the technology and business objectives of a company, needs very careful consideration and participation of many managers and experts. That is why it is sometimes difficult to even collect together these people in an internationally distributed company. Once this part of the hierarchy has been formulated and mutually prioritized the distribution of the "knowledge" all over the organization is very welcome and useful even in the case that it is not used in any Expert Choice-analysis.

- repetitive use of AHP-hierarchy rationalizes decision making

If the same upper part of the hierarchy were used e.g. four times, a significant amount of time and energy would be saved, just-because of smaller amount of modelling and judging work.

- repetitive use of $A H P$-hierarchy directs separate decisions toward the same goal

In decision making the uppermost level has the most influence on the choice. For the Expert Choice users this comes perfectly clear when taking look on to the "global priorities". The elements directly below the goal have the highest global priorities. The priorities of these elements direct most efficiently the choice. If we can use the same upper part repetitively, then we direct the decisions to the same direction. This is also what the company management wants to do.

\section{Mathematical considerations}

As stated in the chapter 2.1., decision theories and mathematical analysis are limited out of the scope of this study. However, it is good to list down some of the mathematical aspects coming from the features of AHP-modelling, that has some impact on the repetitive use of the hierarchy. There are actually three of them:
A. Rank reversal
B. Structural adjustment
C. Meaning of priorities

\section{A. Rank reversal}

When a relative or absolute measurement is used in ranking many elements, changing the model structure (adding or deleting elements) leads to changes in the allocated portions of priority. Consequently the ranking of alternatives changes. This phenomenon is often called rank reversal.

This mathematical phenomenon in the measuring leads to a limitation, that the structure of copied hierarchy shall not be edited. No additional elements shall be taken nor deleting of elements shall be done. This limitation would have been taken into account in any casc, because a change in the structure leads to a new judgement session and that is what is aimed to be avoided by the repetitive use of AHP-hierarchy.

\section{B. Structural adjustment}

In the relative measuring techniques, that AHP is based on, the priority of a node is distributed to the elements that are below that node. Thus, elements that have many peers suffer compared to those elements that are in a group, where there are only few peers. This can be automatically handled by the so called structural adjustment in Expert Choice. This 
feature mathematically eliminates the unfavour coming from the unbalanced hierarchy structure.

Structural adjustment is recommended to be done after a hierarchy is copied and the low'er part (the application specific part) has been built. An other possibility is to manage this problem by giving instructions to the users to build always equally balanced structures.

C. Meaning of priorities

The meaning of the priorities in a AHP-hierarchy is that the priority numbers express how much of the upper level "power" will be distributed to each element. When the decision maker defines priorities, the question hears "what is the importance of this and this in respect to the upper element". This means, that if a level with its priorities is intended to be used in several decision problems, the goal shall be exactly the same and only the uppermost level of AHP-hierarchy should be copied. If there are such nodes in the copied part of hierarchy, that are not common to the problems, then the priorities cannot be copied. The danger is too high for this if more than one level are copied.

\section{Structure of the study}

In which situation can we copy the uppermost part of AHP-hierarchy from one problem to another? Both the structure and the priorities have to be copied to get the benefit aimed. In the previous chapter we defined some considerations coming from the AHPmathematics but now we concentrate only on to the methodological and judgmental aspects. There are two tools used in this empirical study: systems analysis and case studies (fig.4).

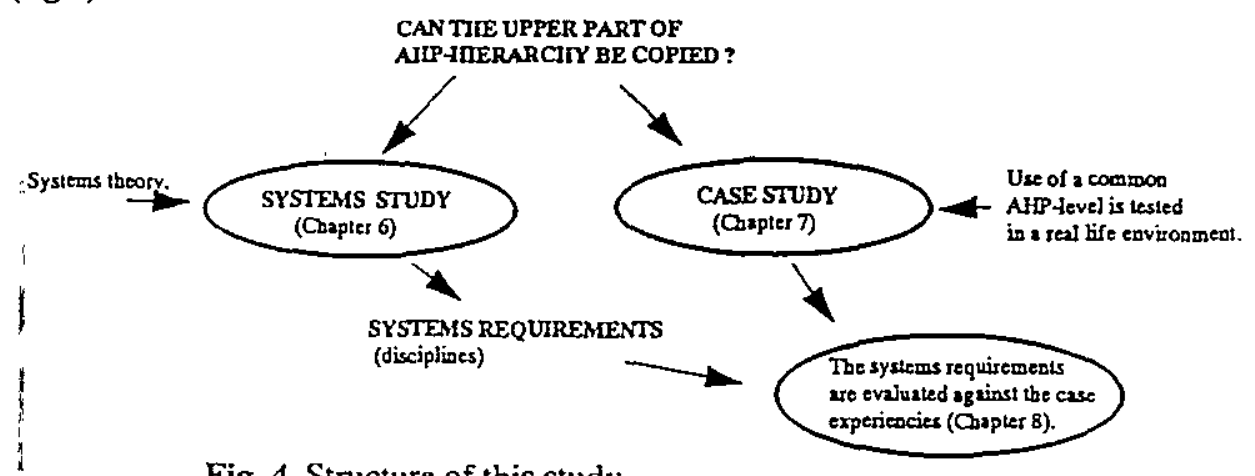

Fig. 4 Structure of this study.

The systems study;

A system is a transformation process whose output can be predicted with a cenain probability if the inputs are known. In engineening sciences systems analysis is very widely used. For example a chemical process is a very well defined system. This kind of "hard system" is illustrated in figure 5. In "hard engineering" the modelling of a system is rather easy.

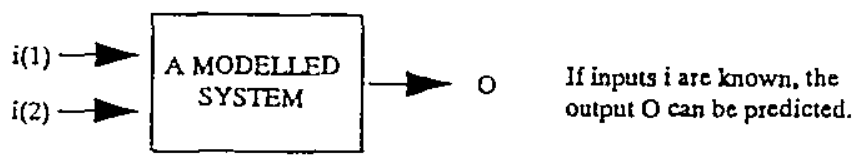

Fig. 5 Hard "engineering" system 
The systems approach in this study starts from an assumption, that a group of problem solving processes form is a system if the problems are similar enough. However, the output from this system is not the solution for a decision problem but the output is a prioritized uppermost level of a AHP-hierarchy. A single problem modelling process can be described as in the figure 6 .

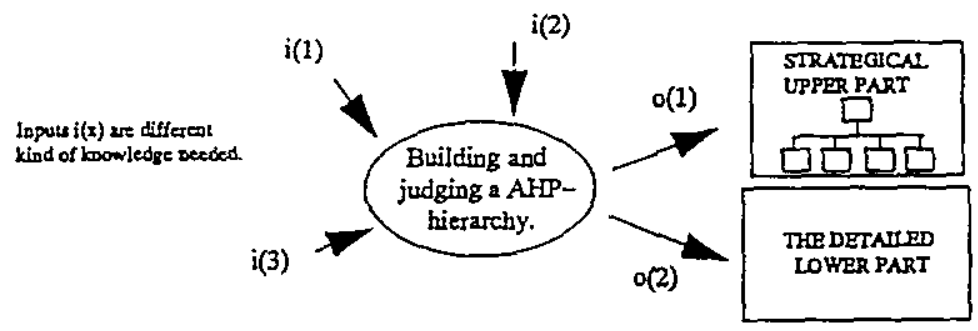

Fig. 6 A single problem modelling process

When we at an electronics production plant make several technology decisions annually, a chain of repetitive modelling processes builds up (see fig.3). One part of the knowledge needed (e.g. $i(1)$ and $i(2)$ ) is common to all of the cases and the repetitive modelling of the uppermost level form a system, which output can be predicted (fig.7). In practice the common knowledge in production technology decisions might be the knowledge about the strategical objectives of the company and the preferences of them. This remains the same from case to case.

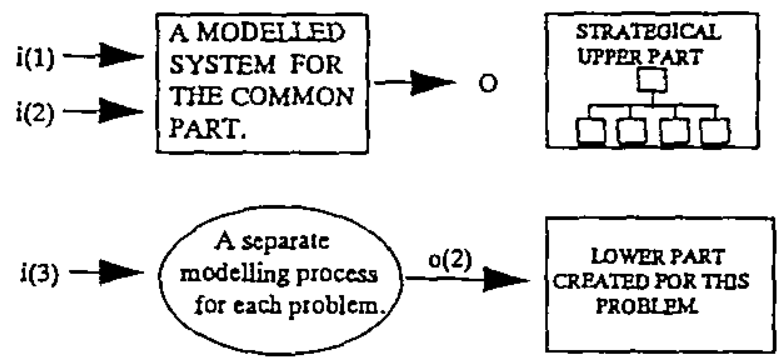

Fig 7. The repetitive modelling of the uppermost level is a "human activity system"

This kind of human activity system is much more difficult to describe and model than the hard engineering system. There is a lot of research done in the field of engineering systems (the "hard systems") but not very much in the field of human activity systems (the "soft systems"). However, the approach developed by Checkland (1985), fits quite well in this case and is also easy to implement into practice.

In this study the target is to define the boundaries, by which we can define when the AHPmodelling processes belong to the same system. The basic assumption is, that as long as the knowledge needed in judging the uppermost level remains the same, we can use the same uppermost level in all of the decision problems within this system (within this group of problems). 
The case study;

Case study is a widely used tool in empirical research. The idea is to analyse some example cases in order to be able to draw some more generally valid conclusions. In this study the cases are used in this manner. The intention is to prove that the same upper part of AHPhierarchy could have been used in several case problems.

?

\section{Systems study}

Checkland (1985) considers the "soft system" (S) to be a human activity system, output of which is a decision to take certain actions. Checkland describes and studies the differences between hard and soft systems as well as forms the basic reasoning to a conceptual management of human activity systems. He ends up to a description, that modelling of such a system (S) includes seven phases; unstructured problem situation, structured problem situation, root definition of relevant system, conceptual modelling, comparison of problem situation and model, list of feasible changes and finally action to improve the problem situation.

Checkland gives a definition for a system (S); (S) is a formal system if, and only if the requirements in the table 1 are fulfilled. In the right column the requirements are interpreted for our case, where the system is the chain of AHP-modelling processes.

Table 1 Systems requirements for a "human activity system"

\begin{tabular}{|c|c|c|}
\hline & $\begin{array}{l}\text { Requirements for a human activity } \\
\text { system Checkland (1985). }\end{array}$ & $\begin{array}{l}\text { Interpretation to the system of copying } \\
\text { the uppermost level of AHP-hierarchy }\end{array}$ \\
\hline $\mathbf{i}$ & S has an on-going purpose or mission. & $\begin{array}{l}\text { All of the decision probjems shall have the same } \\
\text { purpose. }\end{array}$ \\
\hline ii & $\begin{array}{l}\text { S has a measure of perfonmance, which signals } \\
\text { progress or regress in pursuing purposes. }\end{array}$ & $\begin{array}{l}\text { The goal shall be measurable. In AHP this } \\
\text { requirement is always fulfilled. }\end{array}$ \\
\hline iii & $\begin{array}{l}\text { S contains a decision-taking process. Via } \\
\text { decision taking process the systern may take } \\
\text { regulatory action in the light of (ii) and (i). }\end{array}$ & $\begin{array}{l}\text { In AHP-modelling process this requirement is } \\
\text { always fulfilled. }\end{array}$ \\
\hline iv & $\begin{array}{l}S \text { has components that are themselves systems } \\
\text { having all the properties of } S \text {. }\end{array}$ & $\begin{array}{l}\text { In this case the component is a single decision } \\
\text { probleri. If the decision problem repeated exactly } \\
\text { in the same form then the whole AHP-hierarchy } \\
\text { could be copied. This "component" can in theory } \\
\text { be a sub-system. This requirement is thus fulfilled. }\end{array}$ \\
\hline $\mathrm{v}$ & $\begin{array}{l}\text { S has components that interact, which show a } \\
\text { degree of connectivity such that effects and } \\
\text { actions can be transmitted through the system. }\end{array}$ & $\begin{array}{l}\text { The separate decision problems shall be clearly } \\
\text { connecled to each other. }\end{array}$ \\
\hline $\mathrm{vi}$ & $\begin{array}{l}\text { S exists in wider systems or environments with } \\
\text { which it interacts. }\end{array}$ & $\begin{array}{l}\text { The separate problems are in the same environment } \\
\text { with which the modelling processes interact. }\end{array}$ \\
\hline vii & $\begin{array}{l}\text { S has a boundary, separating it from (vi), within } \\
\text { which the decision-taking process has power to } \\
\text { cause action to be taken. }\end{array}$ & $\begin{array}{l}\text { Each decision made has a specific power or effect } \\
\text { within certain limits. The limits of power shall be } \\
\text { the same for all of the separate decision problems. }\end{array}$ \\
\hline viii & $\begin{array}{l}\text { S has resources, which are at the disposal of the } \\
\text { decision-taking process. }\end{array}$ & $\begin{array}{l}\text { The resources used inside the system are the people } \\
\text { defining the structure and priorities of the } \\
\text { uppermost level. The resources are in the disposal } \\
\text { of all the problem modelling processes when the } \\
\text { uppermost Jevel is copied. }\end{array}$ \\
\hline $\mathrm{ix}$ & $\begin{array}{l}\text { S has some guarantee of continuity. This might } \\
\text { derive internally from participants' commitment } \\
\text { to (i). }\end{array}$ & $\begin{array}{l}\text { The people doing the modelling shall be committed } \\
\text { to (i). }\end{array}$ \\
\hline
\end{tabular}


By deleting those requirements that are automatically fulfilled in the case of AHPmodelling process we end up to the applied systems requirements (table 2). The assumption is, that the decision problems, that mutually fulfil the disciplines in table 2 , form a specific group of decision problems and the modelling and judging of the uppermost level is a system.

Table 2. Systems requirements for "a group of decision problems"

\begin{tabular}{|l|l|}
\hline $\mathrm{a}$ & All of the decision problems shall have the same purpose. \\
\hline $\mathrm{b}$ & The separate decision problems shall be clearly connected to each other. \\
\hline $\mathrm{c}$ & $\begin{array}{l}\text { The separate problems are in the same environment with which the modelling } \\
\text { processes interact. }\end{array}$ \\
\hline $\mathrm{d}$ & $\begin{array}{l}\text { Each decision made has a specific power or effect within certain limits. The limits of } \\
\text { power shall be the same for all of the separate decision problems. }\end{array}$ \\
\hline $\mathrm{e}$ & The people doing the modelling shall be committed to (a). \\
\hline
\end{tabular}

\section{Case study}

\subsection{Introduction to the cases}

The case company, Nokia, is an intemational telecommunications and electronics group with 25.500 employees. In the recent years the most successful businesses have been digital telecommunications networks business and mobile telephone business. Nokia is known as a quick moving and innovative player in these businesses and the Nokia way of doing things may differ from those of competitors. In this paper the strategies and general features of the company are not the subject of study. The author of this paper has worked for 5 years in one of its business units as a development manager of production technology and has personally been involved into the cases.

Production technology decisions in companies like Nokia are today much more complicated and more risky than some years ago. The decision environment can be described by the following features; the development, sales and production resources are distributed to several locations, the decisions are very investment oriented, decision shal! be made and implemented quickly, wrong decisions are forbidden (no recovery), a wide and deep technical and business expertise is needed. In this business unit there are annually about 3-5 such production technology decisions made, which have a significant effect on the successfulness of business. Those are either big investment decisions or decisions that have effect on the competitiveness of products.

\subsection{Cases}

The cases for this study are the production technology decisions made during 19881992. The case decisions are listed in the table 3. Some of the cases have been introduced in some context before; there is a reference for this. There is also a note if Exper Choice software was used or not. All of the decisions were made in groups. 
Table 3 Case decision problems

\begin{tabular}{|l|l|l|l|l|}
\hline & The goal of decision & year & Reference & $\begin{array}{l}\text { Was Expert } \\
\text { Choice used? }\end{array}$ \\
\hline C1 & To select an automatic assembly machine. & 1988 & $\begin{array}{l}\text { Verkasalo } \\
(1991)\end{array}$ & Yes \\
\hline C2 & $\begin{array}{l}\text { To decide the SW/HW platform for the factory } \\
\text { computer. }\end{array}$ & 1990 & & No \\
\hline C3 & $\begin{array}{l}\text { To decide the test engineering method/work } \\
\text { procedure. }\end{array}$ & 1990 & No \\
\hline C4 & To select a conveyor system. & 1990 & Yes \\
\hline C5 & $\begin{array}{l}\text { To choose the package size of capacitors for a } \\
\text { new product family. }\end{array}$ & 1991 & Yes \\
\hline C6 & $\begin{array}{l}\text { To decide the manufacturing strategy for a new } \\
\text { production family. }\end{array}$ & 1991 & $\begin{array}{l}\text { Verkasalo } \\
(1991)\end{array}$ & Yes \\
\hline C7 & $\begin{array}{l}\text { To decide if a IS-application will be developed } \\
\text { by own resources or by a SW-house. }\end{array}$ & 1991 & $\begin{array}{l}\text { Verkasalo } \\
(1991)\end{array}$ & Yes \\
\hline C8 & To select a wave soldering machine. & 1991 & & Yes \\
\hline C9 & $\begin{array}{l}\text { To decide the implementation strategy for } \\
\text { DRS-technology. }\end{array}$ & 1992 & Yes \\
\hline C10 & $\begin{array}{l}\text { To select an automatic inspection method for } \\
\text { PCB-assemblies. }\end{array}$ & 1992 & & No \\
\hline C11 & To select the OS for a new generation of ATE & 1992 & & No \\
\hline C12 & $\begin{array}{l}\text { To select the first application for MCM- } \\
\text { technology. }\end{array}$ & 1993 & & Yes \\
\hline
\end{tabular}

Exper Choice has been used also in some other decisions, personal or group decisions, but the others have not had such a big significance on business.

\subsection{Case Analysis}

The cases listed in the table 3 are the "raw material" for this study. The intention is to find out in which extend and within which limitations the same uppermost AHP-hierarchy level could have been used. In the cases, where Expert Choice was used, we know what the decision criteria (elements in the hierarchy) were, but in those cases, where Exert Choice was not used, we don't have exact documentation about the criteria. In the latter cases there is only the author's evaluation, which elements might have been used. In the table 4 all the elements on the uppermost hierarchy level are listed. The marks, that are printed bold are writers evaluations and the marks printed normally are elements from real models. 
Table 4 The elements on the uppermost level in the AHP-hierarchy

\begin{tabular}{|c|c|c|}
\hline & Node names & The cases where this element was present \\
\hline El & $\begin{array}{l}\text { Optimizing the technological } \\
\text { compelitiveness of products. }\end{array}$ & $\mathrm{C} 5, \mathrm{CP}, \mathrm{C} 10, \mathrm{C} 12$ \\
\hline$E 2$ & Broad utilization in business. & $\mathrm{Cl}_{1} \mathrm{C} 3, \mathrm{C} 5, \mathrm{C} 8, \mathrm{C} 9, \mathrm{C10}, \mathrm{C12}$ \\
\hline$\overline{\mathrm{Ej}}$ & Learning of organization. & $\mathrm{C} 3, \mathrm{C} 6, \mathrm{C} 7, \mathrm{C} 9, \mathrm{C} 11, \mathrm{C} 12$ \\
\hline E4 & Risk management. & $\mathrm{Cl}, \mathrm{C}, \mathrm{C}, \mathrm{C} 4, \mathrm{C} 5, \mathrm{C} 6, \mathrm{C} 7, \mathrm{C} 8, \mathrm{C} 9, \mathrm{C} 10, \mathrm{C} 11, \mathrm{Cl} 2$ \\
\hline$\overline{E S}$ & $\begin{array}{l}\text { Short term (1-2 years) economical } \\
\text { optimization. }\end{array}$ & $\mathrm{C} 1, \mathrm{C} 2, \mathrm{C} 3, \mathrm{C} 4, \mathrm{C} 5, \mathrm{C} 6, \mathrm{C} 7, \mathrm{C} 8, \mathrm{C} 9, \mathrm{C} 10, \mathrm{C} 11, \mathrm{C} 12$ \\
\hline E6 & $\begin{array}{l}\text { Long term }(2-5 \text { years }) \text { economical } \\
\text { optimization. }\end{array}$ & $\mathrm{Cl}, \mathrm{C2}, \mathrm{C} 3, \mathrm{C} 4, \mathrm{C} 5, \mathrm{C} 6, \mathrm{C}, \mathrm{C} 8, \mathrm{C} 9, \mathrm{C} 10, \mathrm{C} 11, \mathrm{Cl} 2$ \\
\hline E7 & Human aspects. & $\mathrm{Cl}, \mathrm{C} 2, \mathrm{C} 3, \mathrm{C} 4, \mathrm{C} 5, \mathrm{C} 6, \mathrm{C} 7, \mathrm{C} 8, \mathrm{C} 9, \mathrm{C} 10, \mathrm{C} 11, \mathrm{C} 12$ \\
\hline E\& & $\begin{array}{l}\text { Ulilization of Jatest production } \\
\text { technologies. }\end{array}$ & $\mathrm{C}, \mathrm{C}, \mathrm{Cl0}, \mathrm{Cl1}, \mathrm{C} 12$ \\
\hline E9 & Management of change. & $\mathrm{C}, \mathrm{C} 5, \mathrm{C} 6, \mathrm{C} 9, \mathrm{Cl0}, \mathrm{C11}$ \\
\hline E10 & Management of production process. & $\mathrm{C} 1, \mathrm{C} 4, \mathrm{C} 5, \mathrm{C}, \mathrm{C}, \mathrm{C} 12$ \\
\hline E11 & Commercjal terms. & $\mathrm{Cl}, \mathrm{C}, \mathrm{C} 4, \mathrm{C}, \mathrm{C} 8$ \\
\hline $\bar{E} 12$ & Supplier assessment. & $\mathrm{C} 1, \mathrm{C} 2 ; \mathrm{C} 4, \mathrm{C} 7$ \\
\hline $\mathrm{E} 13$ & $\begin{array}{l}\text { References of a new } \\
\text { machine/lechnology. }\end{array}$ & $\mathrm{C} 1, \mathrm{C2}, \mathrm{C} 4, \mathrm{C} 5, \mathrm{C}, \mathrm{C}, \mathrm{C} 10, \mathrm{C} 12$ \\
\hline E14 & $\begin{array}{l}\text { Performance characteristics of a } \\
\text { machine/lechnology. }\end{array}$ & $\mathrm{C} 1, \mathrm{C} 2, \mathrm{C} 4, \mathrm{C} 5, \mathrm{C} 8, \mathrm{C} 10, \mathrm{C} 11, \mathrm{C} 12$ \\
\hline E15 & $\begin{array}{l}\text { Optimization of material } \\
\text { management. }\end{array}$ & $\mathrm{C} 5, \mathrm{C} 6, \mathrm{C9}, \mathrm{C} 12$ \\
\hline E16 & Business flexibility. & $\mathrm{Cl}, \mathrm{C} 2, \mathrm{C} 3, \overline{\mathrm{C}} 4, \mathrm{C} 6, \mathrm{C} 9, \mathrm{C} 12$ \\
\hline
\end{tabular}

For easier research the tabile 4 is converted to a form of relation matrix (table 5). Number 1 indicates that the element has been used and number 0 indicates that the element is not needed.

Table 5 Relation matrix between cases and elements

\begin{tabular}{|l|l|l|l|l|l|l|l|l|l|l|l|l|l|}
\hline & C1 & C2 & $C 4$ & $C 7$ & $C 8$ & & $C 3$ & $C 5$ & $C 6$ & $C 9$ & $C 10$ & $C 11$ & $C 12$ \\
\hline E1 & 0 & 0 & 0 & 0 & 0 & & 0 & 1 & 0 & 1 & 1 & 0 & 1 \\
\hline E2 & 1 & 0 & 0 & 0 & 1 & & 1 & 1 & 0 & 1 & 1 & 0 & 1 \\
\hline E3 & 0 & 0 & 0 & 1 & 0 & & 1 & 0 & 1 & 1 & 0 & 1 & 1 \\
\hline E4 & 1 & 1 & 1 & 1 & 1 & & 1 & 1 & 1 & 1 & 1 & 1 & 1 \\
\hline E5 & 1 & 1 & 1 & 1 & 1 & & 1 & 1 & 1 & 1 & 1 & 1 & 1 \\
\hline E6 & 1 & 1 & 1 & 1 & 1 & & 1 & 1 & 1 & 1 & 1 & 1 & 1 \\
\hline E7 & 1 & 1 & 1 & 1 & 1 & & 1 & 1 & 1 & 1 & 1 & 1 & 1 \\
\hline E8 & 0 & 0 & 0 & 0 & 0 & & 0 & 1 & 0 & 1 & 1 & 1 & 1 \\
\hline E9 & 0 & 0 & 0 & 0 & 0 & & 1 & 1 & 1 & 1 & 1 & 1 & 0 \\
\hline E10 & 1 & 0 & 1 & 0 & 1 & & 0 & 1 & 0 & 1 & 0 & 0 & 1 \\
\hline E11 & 1 & 1 & 1 & 1 & 1 & & 0 & 0 & 0 & 0 & 0 & 0 & 0 \\
\hline E12 & 1 & 1 & 1 & 1 & 0 & & 0 & 0 & 0 & 0 & 0 & 0 & 0 \\
\hline E13 & 1 & 1 & 1 & 1 & 1 & & 0 & 1 & 0 & 0 & 1 & 0 & 1 \\
\hline E14 & 1 & 1 & 1 & 0 & 1 & & 0 & 1 & 0 & 0 & 1 & 1 & 1 \\
\hline E15 & 0 & 0 & 0 & 0 & 0 & & 0 & 1 & 1 & 1 & 0 & 0 & 1 \\
\hline E16 & 1 & 1 & 1 & 0 & 0 & & 1 & 0 & 1 & 1 & 0 & 0 & 1 \\
\hline
\end{tabular}


In-table 5 the cases have been divided into two groups: group $1(\mathrm{C} 1, \mathrm{C} 2, \mathrm{C} 4, \mathrm{C}, \mathrm{C} 8)$ and group 2 (C3, C5, C6, C9, C10, C11, C12). The elements E1, E8, E9 and E15 have never been used in group 1 decisions and elements E11 and E12 never in group 2 decisions. The êlements needed have been:

Group 1 E2, E3, E4, E5, E6, E7, E10, E11, E12, E13, E14, E16

Group 2 E1, E2, E3, E4, E5, E6, E7, E8, E9, E10, E13, E14, E15, E16

"Most of the elements E1...E16 are sub-goals below which the detailed criteria are. Actually, the strategical objectives of the company are above the elements E1...E16. When we 1 construct a "business objective" level and locate the elements below the objectives, we get the uppermost level of AHP-hierarchy to the both groups of problems (fig. 8 and fig. 9). These could have been used in all of the case problems belonging to the group.

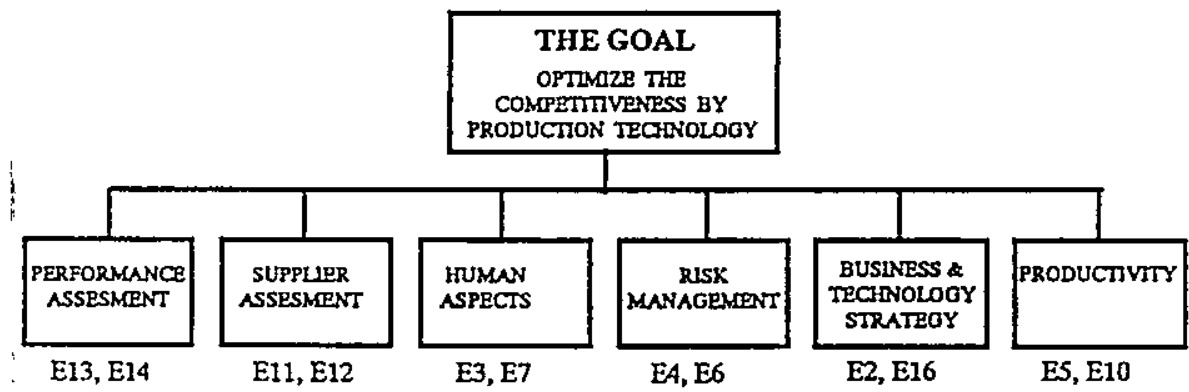

? Fig 8. A common uppermost level for the group 1

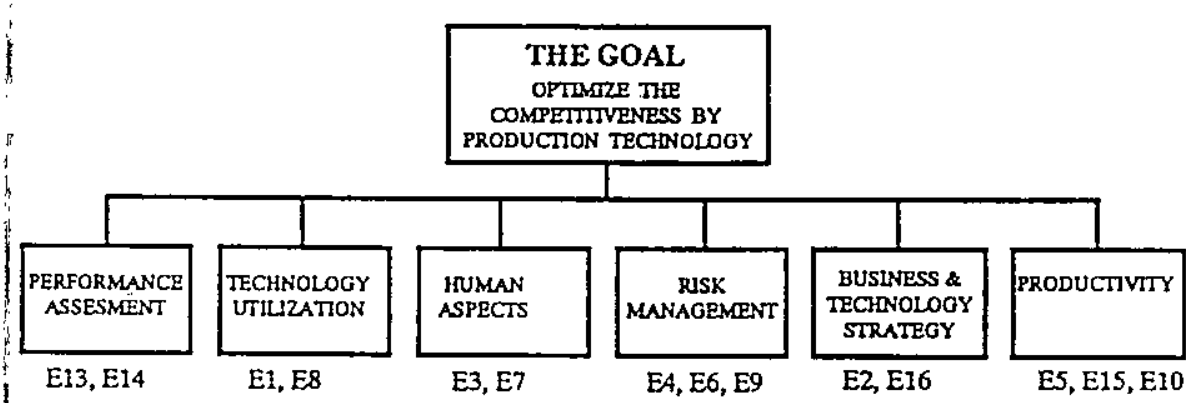

1

Fig 9. A common uppemost level for the group 2

Conclusions from the case analysis are:

Conclusion 1

By analysing the structures of AHP-models we could find two separate groups of decision problems in spite of the same goal. The group 1 consists of technical investment decisions and at least one alternative in each of these cases was to buy something from outside the company. The group 2 consists of decisions, where the aim was to improve the competitiveness of product by production technology means.

Conclusion 2

Only the structure of the AHP-hierarchy was analysed. The priorities of the elements differ from case to case because of the rather long period of data collection (4 years). The 
weighting of objectives and sub-goals in the business strategy change continuously which reflects as changes in priorities.

\section{Conclusion 3}

The decision goal and the elements (in this case the business objectives), that are meant to be used multiple times, shall not be named and defined only for one specific problem but the common elements shall be a general ranked definition of the mutual outline for a group of decisions of the same type.

\section{Conclusion 4}

When the common "uppermost level" of AHP-hierarchy is perceived according to the conclusion 3, the priorities on this level are dependable only on the goal and not on the structure of the lower AHP-hierarchy. This conclusion is also supported by the AHPtheory (see chapter 4, C).

\section{Systems requirements in the cases}

In the chapter 5 a set of criteria for a "human activity system" was defined according to a literature reference. The requirements were screened further to apply a AHP-modelling process. Now we can analyse whether the case study and the systems theory support each other. The analysis is done in table 6 , where each of the systems requirements is answered both within the both groups of cases and between the two groups.

Table 6 Analysis whether the systems requirements are fulfilled in the cases

\begin{tabular}{|c|c|c|c|}
\hline $\begin{array}{l}\text { System requirement. } \\
\text { (from table } 2 \text { ) }\end{array}$ & $\begin{array}{l}\text { Group } 1 \\
\text { Cases } \mathrm{Cl}, \mathrm{C} 2, \mathrm{C} 4, \mathrm{C} 7, \mathrm{C} 8\end{array}$ & $\begin{array}{l}\text { The two } \\
\text { groups are } \\
\text { compared. }\end{array}$ & $\begin{array}{l}\text { Group } 2 \text { Cases C3, C5, } \\
\mathrm{C} 6, \mathrm{C} 9, \mathrm{C} 10, \mathrm{C} 11, \mathrm{C} 12\end{array}$ \\
\hline $\begin{array}{l}\text { a) All of the decision } \\
\text { problems shall have the } \\
\text { same purpose. }\end{array}$ & $\begin{array}{l}\text { Yes. } \\
\text { The purpose is to increase } \\
\text { competitiveness by production } \\
\text { technological means. }\end{array}$ & Yes. & $\begin{array}{l}\text { Yes. } \\
\text { The purpose is to increase } \\
\text { competitiveness by production } \\
\text { technological means. }\end{array}$ \\
\hline $\begin{array}{l}\text { b) The separate decision } \\
\text { problems shall be clearly } \\
\text { connected to each other. }\end{array}$ & $\begin{array}{l}\text { Yes. } \\
\text { The problems are connected to } \\
\text { each other because they are } \\
\text { funded from the same source } \\
\text { and have to fulfil equal } \\
\text { requirements. }\end{array}$ & No & $\begin{array}{l}\text { Yes. } \\
\text { The decision are connected to } \\
\text { each other, because the same } \\
\text { business will benefit or suffer } \\
\text { from all of them. }\end{array}$ \\
\hline $\begin{array}{l}\text { c) The separate problems } \\
\text { are in the same } \\
\text { environment with which } \\
\text { the modelling processes } \\
\text { interact. }\end{array}$ & $\begin{array}{l}\text { Yes. } \\
\text { The environment is the } \\
\text { production plant with its } \\
\text { people. }\end{array}$ & No & $\begin{array}{l}\text { Yes. } \\
\text { The environment is the } \\
\text { production plant and the R\&D } \\
\text { departments. }\end{array}$ \\
\hline $\begin{array}{l}\text { d) Each decision made has } \\
\text { a specific power or effect } \\
\text { within certain limits. The } \\
\text { limits of power shall be } \\
\text { the same for all of the } \\
\text { decision problems. }\end{array}$ & $\begin{array}{l}\text { Yes. } \\
\text { Each decision has power only } \\
\text { over this production facility. }\end{array}$ & No. & $\begin{array}{l}\text { No. } \\
\text { Some of the decisions have } \\
\text { power over a wider range of } \\
\text { products than some other. }\end{array}$ \\
\hline $\begin{array}{l}\text { e) The people doing the } \\
\text { modelling shall be } \\
\text { committed to (a). }\end{array}$ & $\begin{array}{l}\text { Yes. } \\
\text { In all of the cases people are } \\
\text { committed to the same goal. } \\
\text { (a). }\end{array}$ & $\begin{array}{l}\text { Yes. } \\
\text { The key } \\
\text { people are the } \\
\text { same in the } \\
\text { both groups. }\end{array}$ & $\begin{array}{l}\text { Yes. } \\
\text { In all of the cases people are } \\
\text { committed to the same goal (a). }\end{array}$ \\
\hline
\end{tabular}


Conclusions from table 6 are:

\section{Conclusion 5}

The systems requirements a), b), c) and e) (corresponding the $i, v, v i$ and ix requirements from Checkland (1985)) are fulfilled within both of the groups $\rightarrow \rightarrow$ they obviously can be used to check if a decision problem belongs to a specific group or not.

\section{Conclusion 6}

The requirements b) and c) have an extra meaning in differentiating the groups from each other.

\section{Conclusion 7}

The requirement d) seems not to be valid even within a group. This requirement refer to a post decision situation, that has necessarily no effect on the choice.

Are the systems requirements a), b), c) and e) enough to guarantee both the structure and the priorities on the uppermost level of AHP-hierarchy to be valid in several decision problems? The requirements define the problem modelling in the following way:
a) $\rightarrow \rightarrow$ the goal is the same
b) $\rightarrow-\rightarrow$ the problems have a connection to each other
c) $\ldots \rightarrow>$ the decisions are made in the same environment
e) $-\rightarrow>$ the decision makers are committed to the goal (that is common)

The author has not experienced or found from literature any other requirements, that would be needed to complete the above mentioned ones.

\section{Proposals for practical implementation}

This new possibility, to be able to use the same uppermost level of AHP-hierarchy within a group of decision problems, offers a new approach to utilize DSS in practice (see chapter 3). The common part of the hierarchy (in this case the strategical objectives of a company) can be defined and prioritized separately. This is usually done by a partly different team than the one doing the problem specific criteria and alternative assessment. A DSS, where the çopying feature is really taken account, includes the following functions:

\section{ADVISORY FUNCTION}

- the users shall be clearly aware of the limitations of copying

l -also the elements on the uppermost level shall be exceptionally clearly described to prevent misunderstanding

\section{MANAGEMENT OF THE UPPERMOST LEVEL}

- the common elements can be structured and prioritized by Expert Choice

- however, the distribution, copying and documentation of it should be done in a system where it is centrally managed but in the direct use of a rather big group of people in a multi-site organization

INTERFACED TO EXPERT CHOICE

- Expert Choice has the most advanced features to utilize AHP

- ranking, synthesis and sensitivity analysis should be done in Expert Choice

- the basic modelling can be done either in Expert Choice or in the system where the common level is managed 
The author has made a SW demo of the two first mentioned features by TOOLBOOKhypermedia generator.

\section{Conclusions}

The purpose of this empirical study was to search for disciplines within which the uppermost level of a AHP-hierarchy could be used in several decision problems. The outcome was that with very strict rules and caution this is possible. The same uppermost level of AHP-hierarchy can be used in several decisions, if the problems form a coherent group. The group is defined by methodological and AHP-theory based disciplines.

The methodological limitations are:

- the problems have the same goal/purpose

- the problems are connected to each other

- the decisions are made in the same environment

- the people doing the decisions are committed to the goal (that is common)

The AHP-theory based limitations are;

- the structure of the uppermost level shall not be edited (to prevent rank reversal)

- structural balance shall be managed (possibly utilize the "structural adjustment")

- only the uppermost level can be copied (if more than one level is copied the limitations are much stricter than the ones listed here)

\section{References}

Checkland, P., (1985), Systems Thinking, Systems Practice, John Wiley \& Sons, Chichester.

Forman', E., Forman, M., Saaty, T.L., (1993), Expert Choice Version 8 User Manual, Expert Choice Inc., Pittsburgh.

Saaty, T.L., (1980), The Analytic Hierarchy Process, McGraw-Hill, New York.

Verkasalo, M., Parkkinen, R. and Lappalainen, P., (1989), "System Design Methodology in Mechatronics", Proceedings of The 4th International Conference on Product Design for Manufacture \& Assembly, June 5-6-, 1989, Boothroyd Dewhurst Inc, Rhode Island

Verkasalo, M., and Parkkinen, R., (1991), "AHP in High Tech production Decisions", Proceedings of The 2nd International Symposium on The Analytic Hierarchy Process, Joseph M.Katz Graduate School of Business, Pittsburgh, 319-328.

Verkasalo, M., (1992), "Applied Research Promotes the Evolution of DSS", Joint Intemational Conference EURO XII / TIMS XXXI, Helsinki 